\title{
MENINGKATKAN KEMAMPUAN BERPIKIR KRITIS MATEMATIK SISWA SMP MELALUI PENDEKATAN PROBLEM POSING
}

\author{
Tutit Sarimanah \\ SMP Negeri 1 Cianjur \\ tutitsarimanah@yahoo.com
}

\begin{abstract}
ABSTRAK
Kemampuan berpikir kritis matematik penting dimiliki siswa secara global seiring dengan perkembangan jaman dan kemajuan teknologi, karena persoalan kehidupan sehari-hari akan semakin kompleks. Tujuan penelitian ini untuk mengetahui adanya peningkatan kemampuan berpikir kritis matematik siswa SMP dengan menggunakan pendekatan problem posing. Penelitian ini merupakan penelitian eksperimen, dimana ada dua kelas yang diberi tindakan, yaitu kelas eksperimen dan kelas kontrol. Populasi penelitian ini adalah siswa SMP kelas VIII, sedangkan sampelnya adalah dua kelas dari sepuluh kelas yang ada. Instrumen yang diberikan berbentuk uraian. Instrumen yang diuji adalah pretest dan posttest, pretest diberikan sebelum pembelajaran, dan posttest setelah pembelajaran. Data hasil Penelitian dari kelas eksperimen dan kelas kontrol diolah dengan menggunakan SPSS 24.0, kemudian nilai tersebut dianalisis yaitu dengan melakukan uji normalitas uji homogenitas varians dan uji signifikan perbedaan dua rerata. Berdasarkan analisis dan pembahasan dapat disimpulkan bahwa terdapat perbedaan peningkatan kemampuan berpikir kritis matematik siswa SMP yang pembelajarannya menggunakan problem posing lebih baik dibandingkan dengan yang menggunakan pembelajaran biasa.
\end{abstract}

Kata kunci: berpikir kritis matematik, problem posing

\section{PENDAHULUAN}

Matematika sebagai ilmu dasar dari segala bidang ilmu pengetahuan merupakan hal yang sangat penting untuk kita ketahui. Oleh sebab itu, matematika perlu diajarkan di semua jenjang pendidikan formal, mulai dari sekolah dasar sampai perguruan tinggi. Pentingnya matematika bisa dilihat dari manfaat dan kegunaan matematika dalam kehidupan seharihari , juga bagi perkembangan ilmu pengetahuan. Oleh karena itu, penyempurnaan kurikulum terus dilakukan Depdiknas, antara lain dengan memasukkan kemampuan berpikir logis, analitis, sistematis, kritis dan kreatif sebagai standar kompetensi Mata Pelajaran Matematika yang termuat dalam kurikulum 2006.

Kemampuan berpikir kritis sangat diperlukan oleh siswa mengingat bahwa dewasa ini ilmu pengetahuan dan teknologi berkembang sangat pesat dan memungkinkan siapa saja bisa memperoleh informasi secara cepat dan mudah dengan melimpah dari berbagai sumber dan tempat manapun di dunia. Hal ini mengakibatkan cepatnya perubahan tatanan hidup serta perubahan global dalam kehidupan. Jika para siswa tidak dibekali dengan kemampuan berpikir kritis maka mereka tidak akan mampu mengolah, menilai dan mengambil informasi 
yang dibutuhkannya untuk menghadapi tantangan tersebut. Oleh karena itu kemampuan berpikir kritis adalah merupakan hal yang penting dalam mata pelajaran matematika.

Sejalan dengan pernyataan di atas Sumarmo (2012: 4) mengatakan bahwa pendidikan matematika pada hakekatnya mempunyai dua arah pengembangan yaitu untuk memenuhi kebutuhan masa kini dan masa datang. Kebutuhan masa kini yaitu kebutuhan yang mengarah pada kemampuan pemahaman konsep-konsep yang diperlukan untuk menyelesaikan masalah matematika dan ilmu pengetahuan lainnya. Yang dimaksud kebutuhan masa datang adalah kebutuhan yang mengarah kepada kemampuan nalar yang logis, sistematis, kritis dan cermat serta berpikir objektif dan terbuka untuk menghadapi masa depan yang selalu berubah.

Bayer dalam Hassoubah, 2004, Cotto, 1991, Langlehr, 2003) juga menguraikan berpikir kritis. Kemampuan berpikir kritis matematik adalah adalah berpikir secara beralasan dan reflektif dengan menekankan pembuatan keputusan tentang apa yang harus dipercayai atau dilakukan. Indikator kemampuan berpikir kritis dapat diturunkan dari aktivitas kritis siswa sebagai berikut: Fokus (focus) pada pokok permasalahan; Alasan (reason) yang diberikan logis dan sesuai dengan fokus permasalahan; Kesimpulan (inference) diambil berdasarkan alasan yang tepat; Situasi (situation) mencocokan dengan situasi sebenarnya; Kejelasan (clarity) adanya kejelasan mengenai istilah argumen yang digunakan sehingga tidak salah mengambil keputusan; Tinjauan ulang (overview), mengecek kembali yang sudah diputuskan.

Salah satu pendekatan pembelajaran yang dapat digunakan yaitu pendekatan problem posing. Problem posing adalah adalah pendekatan pembelajaran yang dapat menggali kemampuan matematika, dengan memberikan masalah kepada siswa, kemudian siswa diberikan kesempatan untuk membuat pertanyaan.

\section{METODOLOGI PENELITIAN}

Metode penelitian yang digunakan dalam penelitian ini adalah metode kuasi eksperimen yaitu metode yang tidak memungkinkan peneliti melakukan pengontrolan penuh terhadap variabel dan kondisi eksperimen (Sandjaja dan Albertus, 2006: 125). Pada kuasi eksperimen ini, subjek tidak dikelompokkan secara acak, tetapi peneliti menerima keadaan subyek apa (Ruseffendi, 2005). Penggunaan desain dilakukan dengan pertimbangan bahwa, kelas yang ada telah terbentuk sebelumnya, sehingga tidak dilakukan lagi pengelompokkan secara acak, yang justru akan mengacaukan jadwal pelajaran yang telah tersusun. 
Subjek penelitian ini tidak dikelompokkan secara acak. Dalam penelitian sampel yang digunakan terdiri dua kelompok yaitu kelompok kontral dan kelompok eksperimen, dimana pada setiap kelompok diterapkan pembelajaran yang berbeda. Disain penelitiannya adalah sebagai berikut:

\section{$\mathrm{O} \times \mathrm{O}$}

\section{$\mathrm{O} \mathrm{O}$}

Keterangan:

--- : Pengambilan sampel tidak secara acak

$\mathrm{O} \quad$ : Pretes/postes

$\mathrm{X}$ : Pembelajarn dengan menggunakan pendekatan problem posing

Populasinya seluruh siswa SMP. Selanjutnya yang menjadi sampel penelitian adalah dua kelas dari siswa kelas VIII di salah satu SMP di kabupaten Cianjur. Sampel diambil dengan teknik Purposive Sampling. Menurut Sujana (2005: 8) penelitian eksperimen adalah suatu penelitian yang berusaha mencari pengaruh variabel tertentu terhadap variabel lain dalam kondisi yang terkontrol secara ketat. Pada penelitian ini terdapat dua variabel yaitu variabel bebas dan variabel tidak bebas (variabel terikat). Variabel bebas pada penelitian ini yaitu pendekatan problem posing, sedangkan variabel terikatnya yaitu kemampuan berpikir kritis matematik.

\section{HASIL DAN PEMBAHASAN}

Pengolahan data tes kemampuan berpikir kreatif matematik siswa didasarkan pada skor pretes, postes dan N-gain. Dari skor-skor tersebut nilai rata ( $\bar{x}$ )dan simpangan baku (s) untuk masing-masing kelas dapat diketahui. Berikut ini tabel yang memuat nilai-nilai untuk masing-masing.

Tabel 1. Statistik Deskriptif Data Pretes, Postes dan Gain Ternormalisasi

\begin{tabular}{lllllll}
\hline & \multicolumn{3}{l}{ Kelas Eksperimen } & \multicolumn{3}{l}{ Kelas Kontrol } \\
\cline { 2 - 7 } Data & Pretes & Postes & N-gain & Pretes & Postes & N-gain \\
\hline $\mathbf{N}$ & 38 & 38 & 38 & 37 & 37 & 37 \\
\hline Xmax & 19 & 50 & 1,00 & 16 & 48 & 0,94 \\
\hline Xmin & 2 & 23 & 0,44 & 2 & 10 & $-0,11$ \\
\hline $\bar{x}$ & 9,79 & 37,20 & 0,7589 & 10,03 & 31,54 & 0,6235 \\
\hline $\mathbf{S}$ & 4,783 & 6,964 & 0,1564 & 3,664 & 10,381 & 0,2392 \\
\hline
\end{tabular}




$$
\mathrm{SMI}=50
$$

Berdasarkan Tabel 1 terlihat bahwa rerata hasil postes kemampuan berpikir kritis matematik kelas eksperimen lebih besar dari kelas kontrol, terjadi perbedaan sebesar 5,66 atau $11,32 \%$. Skor ideal max 50. Keduanya termasuk sedang. Dapat dilihat juga bahwa simpangan baku kelas eksperimen 6,964 lebih rendah dari kelas kontrol 10,381, sehingga dapat diartikan bahwa bahwa skor kemampuna kritis kelas eksperimen lebih seragam dibanding kelas kontrol.

Terlihat juga hasil gain kelas eksperimen lebih tinggi dari kelas kontrol , artinya terdapat peningkatan kemampuan kritis matematik pada kelas eksperimen dibanding dengan kelas kontrol. Untuk lebih memperjelas perbedaan rata-rata kelas eksperimen dan kelas kontrol disajikan dengan diagram batang berikut ini

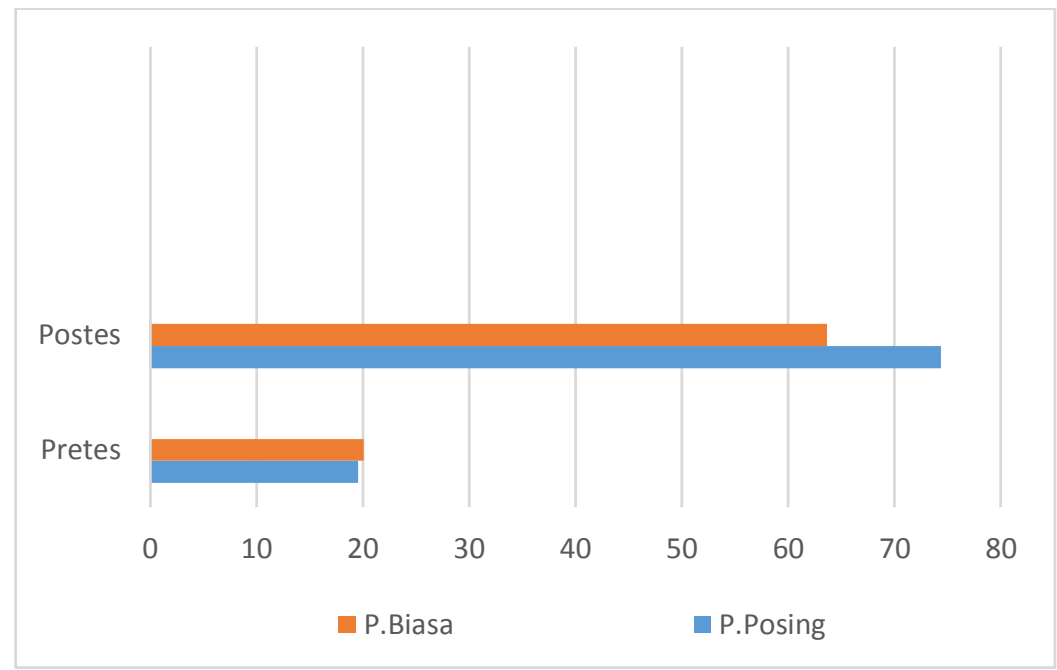

Gambar 1. Grafik Perbedaan Rata-Rata Kelas Eksperimen dan Kelas Kontrol

\section{Analisis Pretest Kemampuan Berpikir Kritis Matematik}

Untuk mengetahui kesetaraan kemampuan pada kelas eksperimen dan kelas kontrol dilakukan uji statistik dengan menggunakan uji kesamaan dua rata-rata.

Tabel 2. Uji Normalias Pretes Kemampuan Berpikir Kritis Matematik

\begin{tabular}{llll}
\hline \multirow{2}{*}{ Kelas } & \multicolumn{3}{l}{ Kolmogorov-Smirnov } \\
\cline { 2 - 4 } & Statistic & Df & Sig. \\
\hline Eksperimen & .112 & 38 & .200 \\
\hline Kontrol & .130 & 37 & .117 \\
\hline
\end{tabular}

Pada Tabel 2, kedua kelas hasilnya $>\alpha$ artinya kedua-duanya normal. Selanjutnya akan dilanjutkan dengan uji homogenitas. Pada uji homogenitas diperoleh sebagai berikut 
Tabel 3. Uji Homogenitas Varians Kemampuan Berpikir Kritis Matematik

\begin{tabular}{llllll}
\hline & & $\begin{array}{l}\text { Levene } \\
\text { Statistic }\end{array}$ & df1 & df2 & Sig \\
\hline Hasil & Based on Mean & .202 & 1 & 73 & .655 \\
\cline { 2 - 6 } Belajar & Based on Median & .165 & 1 & 73 & .685 \\
\hline
\end{tabular}

Pada Tabel 3, terlihat hasilnya Sig nya $=0,655$, lebih dari $\alpha$. Artinya Kedua kelas homogen. Dilanjutkan Uji kesamaan dua rata-rata, hasilnya sebagai berikut

Tabel 4. Uji Kesamaan Dua Rata-rata Skor Pretes Kemampuan Berpikir Kritis Matematik

\begin{tabular}{lllllll}
\hline & & & & & \\
\hline Hasil & E v & .202 & .655 & -430 & 73 & .669 \\
Belajar & As & & & & & \\
\cline { 2 - 7 } & E v & & & -430 & 72,715 & .669 \\
& Not as & & & & & \\
\hline
\end{tabular}

Terlihat dari Tabel Sig $=0,669$. Artinya Ho diterima. Dengan demikian dapat diartikan kedua sampel bahwa tidak ada perbedaan kemampuan awal yang signifikan antara kelas eksperimen dan kelas kontrol.

\section{Analisis Posttest Kemampuan BerpikirKritis Matematik Berdasarkan Pembelajaran}

Untuk melihat apakah kemampuan berpikir kritis matematik siswa yang mengikuti pembelajaran problem posing lebih baik daripada yang mengikuti pembelajaran biasa, maka dilakukan uji perbedaan rata-rata. Sebelum menguji perbedaan rata-rata, akan diuji terlebih dahulu normalitas data.

Tabel 5. Uji Normalitas Posttest Kemampuan Berpikir Kritis Matematik

\begin{tabular}{llll}
\hline \multirow{2}{*}{ Kelas } & \multicolumn{3}{l}{ Kolmogorov-Smirnov } \\
\cline { 2 - 4 } & Statistic & Df & Sig. \\
\hline Eksperimen & .158 & 38 & .018 \\
\hline Kontrol & .173 & 37 & .007 \\
\hline
\end{tabular}

Pada Tabel 5 terlihat bahwa nilai sig 0,018 Hal ini dapat disimpulkan data berdistribusi tidak normal pada taraf signifikansi 5\%. Untuk itu tidak perlu diuji homogenitasnya, langsung diuji perbedaan rata-ratanya dengan Mann-Whitney. 
Tabel 5 Uji Perbedaan Rata-Rata Kemampuan Berpikir Kritis Matematik

\begin{tabular}{lr}
\hline & Hasil Belajar \\
\hline Mann-Whitney U & 475.500 \\
\hline Wilcoxon & 1178.500 \\
\hline Z & -2.416 \\
\hline Asymp.Sig.(2-tailed) & .016 \\
\hline
\end{tabular}

Pada Tabel 5 di atas terlihat Sig. (2-tailed) adalah 0,016> $>$, maka nilai signifikansi untuk pengujian satu pihak dibagi 2 hasilnya 0,008. Dengan demikian maka Ho ditolak. Sehingga dapat disimpulkan bahwa kemampuan berpikir kritis matematik siswa SMP yang mengikuti pembelajaran problem posing lebih baik dibanding dengan mengikuti pembelajaran biasa. Beberapa peneliti lain yang melaporkan bahwa kemampuan berpikir kritis matematik siswa tergolong cukup baik dari kemampuan siswa yang memperoleh pembelajaran konvensional antara lain Syukur (2005) dengan pendekatan open ended terhadap Siswa SMA, Ratnaningsih dengan pendekatan kontekstual terhadap siswa SMA dan Rochaeti terhadap siswa SMP.

\section{Analisis Gain Ternormalisasi Kemampuan Berpikir Kritis}

Untuk melihat apakah terdapat peningkatan kemampuan berpikir kritis matematika siswa yang mendapat pembelajaran dengan menggunakan pendekatan problem posing bila dibanding dengan siswa yang mendapatkan pembelajaran biasa, maka dilakukan pengujian perbedaan dua rerata. Sebelumnya akan diuji terlebih dahulu normalitas data. Hasil uji normalitas menggunakan Uji Kolmogorov-Smirnov (KS) dapat dilihat pada tabel berikut

Tabel 6. Uji Normalias Gain Ternormalisasi Kemampuan Berpikir Kritis Matematik

\begin{tabular}{cccc}
\hline \multirow{2}{*}{ Kelas } & \multicolumn{3}{c}{ Kolmogorov-Smirnov } \\
\cline { 2 - 4 } & Statistic & Df & Sig. \\
\hline Eksperimen & .112 & 38 & .107 \\
\hline Kontrol & .130 & 37 & .044 \\
\hline
\end{tabular}

Berdasarkan Tabel 6 terlihat pada pembelajaran problem posing memilikinilai sig. 0,107 , artinya sampel berdistribusi normal, sedangkan kelas kontrol 0,44 , artinya sampel berdistribusi tidak normal. Jika salah satu sampel berdistribusi tidak normal tidak perlu diuji homogenitasnya, langsung diuji dengan Non Parametrik Mann-Whitney. 
Tabel 7. Uji Gain Ternormalisasi Kemampuan Berpikir Kritis Matematik

\begin{tabular}{lr}
\hline & Hasil Belajar \\
\hline Mann-Whitney U & 454.500 \\
\hline Wilcoxon & 1157.000 \\
\hline Z & -2.635 \\
\hline Asymp.Sig.(2-tailed) & .008 \\
\hline
\end{tabular}

Pada Tabel 7 di atas terlihat Sig. (2-tailed) adalah 0,008 < $\alpha$, maka nilai signifikansi untuk pengujian satu pihak dibagi 2 hasilnya 0,004. Dengan demikian maka Ho ditolak. Sehingga dapat disimpulkan bahwa terdapat peningkatan kemampuan berpikir kritis matematik siswa SMP yang mengikuti pembelajaran problem posing lebih baik dibanding dengan mengikuti pembelajaran biasa.

\section{KESIMPULAN}

Berdasarkan hasil temuan selama penelitian dan analisis data penelitian mengenai kemampuan berpikir kritis matematik siswa melalui pendekatan problem posing dan pembelajaran biasa peneliti memperoleh kesimpulan bahwa pencapaian kemampuan berpikir kritis matematik siswa yang pembelajarannya menggunakan pendekatan problem posing lebih baik dibanding dengan yang menggunakan pembelajaran biasa dan peningkatan kemampuan berpikir kritis matematik siswa yang pembelajaranya menggunakan pendekatan problem posing lebih baik dibanding dengan yang menggunakan pembelajaran biasa.

\section{REFERENSI}

Hassoubah, H. (2004). Develoving Creative \& Critical Thinking Skill (Cara Berpikir Kreatif dan Kritis). Bandung: Yayasan Nuansa Cendekia.

Rochaeti, E.E. (2008). Pembelajaran dengan Pendekatan Eksplorasi untuk Mengenbangkan Kemampuan Berpikir Kritis dan Kreatif Matematika Siswa SMP. Disertasi pada Sekolah Pascasarjana UPI. Tidak diterbitkan.

Rochaeti, E.E. (2010). Critical and Creative Mathematical Thinking of Junior High School Students. Makalah dimuat dalam Educationist, Jurnal Kajian Filosofi Teori Kualitas dan Manajemen Pendidikan. Vol. IV, No.2.

Sumarmo,U. (2012). Berpikir dan Disposisi Matematik serta Pembelajarannya. Jurusan Pendidikan Matematika FP MIPA UPI: Tidak Diterbitkan 